\title{
BAGAIMANA CONSUMER PERCEPTION DAN CONSUMER ATTITUDE MEMPENGARUHI MOTIVASI PEMBELIAN GREEN PRODUCT (KAJIAN PERILAKU KONSUMEN DARI BERBAGAI BUDAYA DAN NEGARA)
}

\author{
Novia Astri Leonora \\ Universitas Ma Chung, Malang
}

\begin{abstract}
Currently, the environmental damage occurs almost throughout the earth. Many people try to find the way to save the environment. It causes the companies to make green products in the contribution of protecting the environtment. But not everyone can accept the green product. This study case choosesvarious countries, such as Niger, China, United States, India, Lesotho, Italia, Sweden, South Korea, and Hong Kong. Not all countries have good perception and good attitude towards green products, but most of them have good perception towards green products and they have good attitude if the green products can give them a benefit. Marketers can give more education about green product to countries which have negative perception and negative attitude towards green product. Marketers also have a big opportunity to market their green product to countries which have a positive perception and positive attitude toward green products
\end{abstract}

Keywords: Consumer perception, consumer attitude, green marketing, green product

\section{PENDAHULUAN}

Saat ini kerusakan lingkungan terjadi secara global. Dengan adanya kerusakan lingkungan secara global ini dapat menggangu kesehatan manusia. Lingkungan saat ini sangat mudah berubah-ubah. Cuaca semakin tidak menentu, lapisan ozon berkurang, dan suhu bumi yang meningkat dapat menyebabkan ketidakseimbangan alam.

Jumlah hutan didunia dari tahun ketahun terus menurun. Pada tahun 2015 jumlah hutan diseluruh dunia hanya 30.8\% (World Bank, 2017). Dengan adanya fenomena kerusakan lingkungan secara global, dapat menyadarkan orang-orang untuk menjaga lingkungannya dengan baik. Baik konsumen maupun produsen mulai berpikir bagaimana mencegah agar lingkungan sekitar tidak bertambah rusak. Hal ini menyebabkan tantangan baru bagi perusahaan, produsen maupun pemilik usaha dalam menyikapi kerusakan lingkungan secara global. Pengusaha atau produsen harus berpikir untuk menciptakan produk-produk yang ramah lingkungan atau bahkan dapat berkontribusi untuk memperbaiki lingkungan yang sudah rusak. 
Green marketing sendiri pada dasarnya menerapkan bagaimana membuat produk atau menghasilkan produk dengan menjaga ekosistem agar lingkungan tetap terjaga kelestariannya. Di mulai dari masyarakat yang sadar dengan pentingnya menjaga lingkungan lalu, perusahaan menerapkan kesadaran masyarakat atas lingkungan. Dengan hal tersebut dapat membuat persepsi masyarakat terhadap perusahaan itu adalah perusahaan tersebut berkontribusi dalam menjaga ekosistem .

Meskipun banyak masyarakat yang mulai menyadari pentingnya kesehatan dan perlunya menjaga lingkungan tetap memiliki persepsi dan sikap yang berbeda terhadap green product. Persepsi dan sikap ini yang perlu diketahui karena ada banyak pendapat masyarakat tentang green product.

Budaya dari suatu negara juga dapat mempengaruhi persepsi dan sikap msyarakat terhadap green product. Dengan budaya yang berbeda dapat mempegaruhi persepsi dan sikap masyarakat. Ada budaya dan negara yang sangat menyukai green product dan ada yang menganggap biasa hal tersebut.

Tujuan pembahasan ini untuk mengetahui bagaimana persepsi dan sikap konsumen terhadap green product. Dengan adanya perbedaan budaya dan negara bagaimana persepsi dan sikap konsumen terhadap green product. Dengan mengetahui hal tersebut, dapat diketahui budaya dan negara mana yang memiliki persepsi dan sikap yang positif terhadap green product. Jika masyarakat memiliki persepsi dan sikap yang positif dapat meningkatkan penjualan dari green product hal tersebut dikarenakan adanya otivasi yang mendorong untuk membeli produk tersebut. Dan pemasar juga dapat mengetahui bagaimana memasarkan green product.

\section{TINJAUAN PUSTAKA}

\section{Persepsi Konsumen}

Menurut Gampu, Kawet, Uhing (2015) persepsi konsumen terhadap suatu produk berasal dari pengaruh beberapa faktor dari dalam maupun dari luar dirinya. Persepsi merupakan sebuah proses dimana seseorang melakukan pemilihan, mengorganisasi, dan mengartikan sebuah masukan informasi untuk menciptakan sebuah gambaran (Saputra dan Semuel, 2013).

Surya dan Setyaningrum (2009) mengatakan bahwa persepsi konsumen memiliki sebuah proses. Proses tersebut diawali dengan konsumen menangkap dan memilih 
stimulus berdasarkan pada berbagai informasi yang telah diterima dan yang ada dipikirannya. Selanjutnya dilakukan proses seleksi. Dalam proses seleksi akan ada proses yang terjadi yaitu meliputi perhatian dan selektif. Perhatian yang dialami konsumen bisa saja terjadi secara sengaja (voluntary attention) dan secara tidak sengaja (involuntari attenton) dimana yang secara sengaja konsumen terlibat dalam mencari sebuah informasi, sedangkan yang tidak sengaja konsumen diberikan berbagai paparan stimuli berupa hal-hal yang menarik secara tidak terduga dan tidak berhubungan dengan tujuan konsumen.

\section{Sikap Konsumen}

Sikap konsumen terbentuk sebagai respon terhadap suatu merek maupun produk termasuk keluhan yang akan disampaikan karena tidak terpenuhinya janji-janji yang ditawarkan (Mini, 2010). Selain itu sikap juga bisa timbul karena keadaan yang dialami orang tetapi juga kejadian yang pernah dialami di masa lalu dan harapan-harapan di kejadian yang akan datang (Mawey, 2013). Sikap juga dapat menempatkan orang kedalam kerangka pemikiran mengenai suka atau tidak suka dan tentang mendekati atau menjauhinya (Tamaka, 2013).

\section{Green Marketing}

Menurut American Marketing Association green marketing merupakan pemasaran produk yang ramah lingkungan. Didalamnya terdapat aktivitas modifikasi produk, merubah proses produksi, merubah kemasan, dan merubah periklanan (Hawkins dan Mothersbaugh, 2010). Menurut Agustin, Kumadji, dan Yulianto (2015) tujuan dari green marketing tidak hanya melihat keuntungan saja yang menjadi tujuan utama tetapi juga ada rasa kepedulian terhadap lingkungan.

\section{Green Product}

Produk hijau adalah gambaran usaha suatu organisasi didalam mendesain,mempromosikan, menawarkan dan mendistribusikan produk yang ramah lingkungan (Susilo, 2012). Produk hijau juga dirancang dan diproses dengan suatu cara yang dapat mengurangi efek-efek yang dapat mencemari lingkungan, baik dalam proses produksi, distribusi dan penjualannya (Hayu, 2014). 


\section{HASIL DAN PEMBAHASAN}

\section{Persepsi dan Sikap Konsumen di Nigeria}

Penelitian Obayelu, Adeoti dan Akinlade (2014) menyatakan bahwa persepsi konsumen dan sikap konsumen mungkin berpengaruh pada keputusan pembelian setiap individu. Persepsi individu berasal dari kesadaran mental yang dipengaruhi oleh stimuli dari internal maupun eksternal seperti ekonomi, sosial dan budaya. Sedangkan sikap konsumen merupakan respon internal.

Dari hasil penelitiannya masyarakat di Nigeria memiliki persepsi yang positif terhadap makanan dan minuman organik yang berlabel dan bersertifikat. Mereka mau membayar lebih mahal untuk moringa tea dan oil yang memiliki label dan bersertifikat. Orang yang memiliki sikap yang baik terhadap produk moringa akan membayar lebih produk yang memiliki label dan sertifikat.

Tetapi sikap masyarakat bisa berbeda jika masyarakat tersebut tidak membeli produk organik dan yang suka membeli suplemen-suplemen diet, tetapi sikap yang positif diberikan jika masyarakat tersebut peduli dengan kesehatan mereka akan membayar lebih terhadap produk moringa yang berlabel dan bersertifikat.

Masyarakat Nigeria yang memiliki persepsi dan sikap yang baik dapat menjadikan motivasi pembelian porduk tersebut. Meskipun tingkat kesadaran akan kualitas mereka akan tetap mau membayar lebih karena ada label dan sertifikat yang merupakan produk yang sudah sesuai degan standar yang sudah ditetapkan.

Hasil yang ditunjukan umur juga berpengaruh terhadap motivasi pembelian. Hal tersebut dikarenakan persepsi dari masyarakat yang sudah mulai berumur membutuhkan nutrisi yang lebih dan bahan-bahan yang natural. Karena orang yang mulai berumur sudah memikirkan kesehatannya sehingga persepsi dan sikap yang baik dapat memotivasi keinginan untuk membeli produk tersebut. Dan diharapkan pemasar lebih baik mempromosikan produknya pada segmen orang yang berumur.

\section{Persepsi dan Sikap Konsumen di China}

Hasil penelitian Xie et al. (2014) mengatakan bahwa sebenarnya pasar di Eastern China menjual berbagai macam makanan dengan berbagai macam label. Masyarakat Eastern China peduli dengan makanan yang aman tetapi banyak yang tidak mengetahui standar makanan yang aman. Dari hasil penelitiannya hanya sebesar 44.8 persen 
masyarakat yang mengetahui arti sesungguhnya dari makanan organik. Hal tersebut menyebabkan masyarakat yang tidak mengetahui benar tentang makanan organik tidak akan membeli makanan organik tersebut. Kebanyakan masyarakat China mengetahui produk tersebut organik dari asisten toko yang menyatakan produk tersebut organik. Penduduk disana menginginkan periklanan tentang produk organik lebih sering.

Harga juga mempengaruhi persepsi konsumen terhadap motivasi pembelian makanan organik. Masyarakat di Eastern China mau membeli makanan organik dengan harga yang lebih tinggi. Masyarakat juga menginginkan adanya garansi untuk makanan organik. Hal tersebut dikarenakan masyarakat ingin percaya jika makanan organik tersebut sudah melalui proses produksi yang optimal dan baik untuk konsumen. Pemerintah di China sendiri juga sudah menetapkan peraturan makanan organik dan akan diberi label khusus.

Pembeli makanan organik merupakan masyarakat kalangan yang berusia dewasa, memiliki pendidikan yang tinggi, memiliki penghasilan yang tinggi dan yang ingin mempunyai anak. Motivasi pembeliannya adalah karena alasan kesehatan, ramah lingkungan dan memiliki rasa yang lebih baik. Dengan mengetahui hal ini pemasar dapat memasarkan produk organik atau makanan organik pada kalangan yang sudah memiliki anak.

\section{Persepsi dan Sikap Konsumen di Amerika}

Hasil penelitian Schubert et al. (2010) mengungkapkan bahwa masyarakat di Amerika percaya jika green restaurant dapat membantu melindungi lingkungan. Hasil penelitian menunjukkan bahwa masyarakat Amerika mau membayar lebih untuk makan di green restaurant. Sikap yang diberikan masyarakat juga baik terhadap green restaurant ini. Tetapi wanita lebih menyukai hal ini dibanding pria.

Hal yang berbeda dari sebelumnya, masyarakat yang usianyadibawah 35 tahun lebih memilih makanan organik dari pada usia 35 tahun keatas. Karena di usia 35 tahun kebawah memiliki persepsi bahwa dengan adanya green reastaurant dapat membantu menjaga lingkungan dan lebih sehat daripada restoran pada umumnya. Sikap yang mereka pilih juga akan memilih makan di green restaurant karena mereka menganggap dengan makan disitu dapat mengurangi energi yang digunakan, menggunakan bahan dari alam atau daur ulang, menggunakan produk lokal, dan donasi untuk proyek lingkungan. 
Dari hal tersebut dapat dilihat, orang mau makan di green restaurant karena persepsi yang memandang hal tersebut tidak akan merusak lingkungan. Hal tersebut dapat dimanfaat kan oleh green restaurant untuk menarik dengan harga yang tinggi. Hal tersebut dikarenakan ada konsep hijau di dalamnya dan sikap mereka yang mendukung hal tersebut dapat memotivasi untuk makan di green restaurant.

\section{Persepsi dan Sikap Konsumen di India}

Hasil penelitian Bhatia dan Jain (2013) menyebutkan bahwa masyarakat di India menyetujui green product dapat menjaga lingkungan. Konsumen juga menyetujui jika perusahaan mampu menjaga lingkungannya. Hal tersebut menunjukkan persepsi konsumen di India sangat mendukung adanya green product untuk menjaga lingkungannya.

Sikap dari masyarakat India juga ingin menjaga lingkungannya. Hal itu ditunjukkan dengan masyarakat mementingkan produk yang tidak membahayakan lingkungan, tidak membuang banyak sampah, mau mengambil tindakan yang dapat menjaga lingkungannya,dan membuat kebiasaan baru untuk membeli produk yang ramah lingkungan.

Konsumen di India mau membayar lebih untuk green product dan lebih memilih green product. Masyarakat di India mengatakan bahwa dengan adanya green marketing dapat membuat perusahaan dan konsumen dapat dijadikan bisnis yang bagus selain peduli terhadap lingkungan. Hal tersebut yang menjadikan motivasi konsumen di India untuk membeli green product. Hal tersebut bisa membuat pemasar di India dan perusahaan dapat mengembangkan green productnya karena orang-orangdi India sebagian besar menyetujui dengan produk yang ramah lingkungan. Orang-orang di India juga mau berkontribusi untuk menjaga lingkungannya.

\section{Persepsi dan Sikap Konsumen di Lesotho}

Menurut Khola, Potiane, dan Mokhethi (2014) masyarakat Lesotho ketika membeli sesuatu memperhatikan barang tersebut ramah lingkungan, baik untuk kesehatan dan berkualitas. Untuk harga masyarakat di Lesotho tidak terlalu memperhatikan karena hal yang diutamakan adalah produk atau barang tersebut ramah lingkungan. Selain itu masyarakat Lesotho memiliki sikap yang baik terhadap green product. 
Tetapi dari hasil penelitian menyebutkan dengan memperhatikan lingkungan belum tentu membuat masyarakat Lesotho mau membeli green product. Hal tersebut dikarenakan masyarakat Lesotho beranggapan menjaga lingkungan harus dengan tindakan nyata bukan hanya dengan membeli green product dan menurut mereka dengan membeli green product hanya untuk kebaikan diri sendiri.

Dengan hal tersebut meskipun persepsi konsumen baik dan sikap yang baik dalam menjaga lingkungan, belum tentu menjadikan motivasi untuk membeli green product. Hal tersebut karena masyarakat Lesotho beranggapan bertindak langsung menjaga lingkungan itu lebih baik daripada membeli green product yang hanya untuk kepentingan individu.

\section{Persepsi dan Sikap Konsumen di New Zealand}

Menurut Gan et al. ( 2008) penduduk New Zealand tidak membeli green product karena penduduk disana memiliki persepsi green product memiliki harga yang tinggi tetapi manfaat yang diberikan rendah.

Hal yang menarik ditunjukan adalah masyarakat New Zealand yang mau membeli green product adalah kalangan usia 18-45 tahun dan yang memiliki tingkat pendidikan yang tinggi memiliki sikap yang positif terhadap lingkungannya. Orang yang sudah menikah juga mau membeli green product. Hal tersebut dikarenakan orang yang sudah menikah lebih mementingkan kesehatan keluarganya termasuk ke generasi yang akan datang. Tetapi mereka tidak mau membayar dengan harga lebih kecuali produk tersebut berasal dari merek yang sudah familiar.

Dari hal tersebut dapat dilihat jika ingin memasarkan green product di New Zealand harus mengetahu target yang tepat. Selain itu juga harus bisa membuat produk yang memiliki kualitas yang tinggi dan harga bersaing. Hal tersebut dikarenakan persepsi masyarakat New Zealand beranggapan bahwa green product tidak memiliki nilai lebih disisi kualitas tetapi harga yang diberikan cukup tinggi.

\section{Persepsi dan sikap konsumen di Italia}

Hasil penelitian Nassivera dan Sillani (2014) menunjukkan orang yang berusia antara 30-50 tahun khususnya wanita lebih memilih untuk membeli makanan organik. Hal tersebut dikarenakan persepsi mereka lebih penting kesehatannya. Kesehatan bagi mereka sangat penting sehingga mereka sampai memikirkan mereka harus memakan makanan 
yang sehat. Sikap yang mereka pilih adalah mereka secepat mungkin harus membeli makanan organik dan mengkonsumsinya.

Dari persepsi konsumen dan sikap konsumen yang seperti itu dapat menjadi motivasi untuk membeli green product khususnya makanan organik. Mereka mau membelinya meskipun harga yang ditawarkan lebih tinggi dari makanan yang biasa. Mereka juga mau membelinya karena mereka mempunyai persepsi bahwa perusahaan atau produsen sangat peduli dengan lingkungan.

Dengan adanya hal tersebut pemasar bisa mencoba membuat produk dengan ecolabel tentunya dengan syarat-syarat dari pemerintah yang harus dipenuhi. Karena jika menggunakan eco-label membuat persepsi orang jika membeli hal tersebut maka meeeka juga merasa berkontribusi menjaga lingkungannya.

\section{Persepsi dan Sikap Konsumen di Swedia}

Hasil penelitian Irandoust (2016) orang Swedia memiliki persepsi negatif terhadap green product. Hal tersebut karena orang Swedia memiliki kepercayaan yang rendah terhadap green label sehingga sangat kecil kemungkinan masyarakat Swedia mau membeli green product.

Dari persepsi tersebut bisa dipastikan masyarakat Swedia hanya sedikit yang mau membeli green product. Selain karena kepercayaannya yang rendah, harga yang sangat tinggi membuat hanya orang yang memiliki penghasilan yang tinggi mau membeli produk tersebut.

Dengan adanya hal tersebut pemasar yang mempromosikan green product perlu menyampaikan pentingnya menjaga kesehatan dan lingkungan. Memberikan informasi yang lebih kepada masyarakat tentang pentingnya menjaga lingkungan dapat menjadi pembelajaran bagi masyarakat Swedia. Karenajika pengetahuannya sudah bagus untuk kepedulain lingkungan dan kesehatan dapat meningkatkan penjualan green product

\section{Persepsi dan Sikap Konsumen di Korea Selatan}

Menurut hasil penelitian Hwang, Park dan Kim (2016) penduduk di Korea Selatan masih memiliki persepsi yang rendah terhadap green product terutama dengan produk yang terdapat eco-label. Hal ini dikarenakan penduduk Korea lebih percaya terhadap produk yang hemat energi daripada produk yang memiliki eco-label. 
Dari persepsi tersebut, penduduk Korea Selatan memilih lebih baik membeli produk yang hemat energi karena memiliki efek yang signifikan ketika digunakan. Selain itu di Korea Selatan kerusakan lingkungan yang sangat rendah sehingga mereka belum peduli jika ada green product.

Dari hasil tersebut pemasar sebaiknya membuat inovasi green product. Penduduk Korea Selatan lebih suka dengan produk yang memiliki manfaat lebih. Hal tersebut bisa menjadi tantangan dalam menciptakan green product yang memiliki manfaat lebih di Korea Selatan. Jika ada green product yang memiliki keuntungan yang lebih dari produk hemat energi, maka bisa menaikkan motivasi pembelian green product di Korea Selatan.

\section{Persepsi dan Sikap Konsumen di Hong Kong}

Menurut penelitain Yau (2012) warga Hong Kong memiliki persepsi pentingnya menjaga lingkungan. Oleh karena itu warga di Hong Kong mau membayar lebih untuk membangun rumah atau gedung yang ramah lingkungan atau Building Environtental Assesment Method (BEAM).

Tetapi meskipun memiliki persepsi harus menjaga lingkungannya, sikap yang ditunjukkan tidak mau membayar lebih untuk BEAM. Hal ini terjadi karena mereka tidak mengerti apa kelebihan dari BEAM sendiri dengan bangunan yang pada umumnya. Warga di Hong Kong memiliki motivasi beli green product jika memiliki manfaat yang jelas. Bahkan mereka mau membayar lebih untuk hal tersebut.

Dengan adanya hal tersebut perlu adanya edukasi tentang BEAM itu sendiri atau bangunan yang ramah lingkungan. Hal tersebut sangat penting karena warga Hong Kong hanya termotivsi membeli green product bila ada manfaat yang lebih untuk lingkungannya. Selain itu jika membangun BEAM perlu adanya garansi supaya orang yang membeli tidak merasa dirugikan dengan harga yang sangat tinggi tersebut.

\section{Persepsi dan Sikap Konsumen di Romania}

Hasil penelitian menyatakan bahwa orang-orang di Roma yang berpendidikan rendah percaya bahwa dengan adanya edukasi tentang makanan organik dapat berkontribusi dalam menyelamatkan lingkungan. Tetapi orang yang berpendidikan tinggi di Romania memiliki persepsi yang rendah. Hal tersebut dikarenakan persepsi orang yang berpendidikan tinggi menanggap tidak ada keuntungan pada lingkungan jika menggunakan 
makanan organik. Tetapi secara keseluruhan memiliki kepercayaan yang tinggi terhadap makanan organik.

Selain itu sikap yang ditunjukkan dengan membelimakanan organik ada motivasi tersendiri. Motivasi tersebut berubah gaya hidup yang fashionable dan gaya hidup yang sehat. Tetapi hasil penelitian menyebutkan motivasi membelimakanan organik tersebut hanya karena termotivasi oleh gaya hidup yang fashionale bukan gaya hidup yang sehat. Dengan adanya hal tersebut pemasar perlu memberikan edukasi yang tepat dari manfaat green product itu sendiri.

\section{Implikasi Manajemen Pemasaran}

Dari kasus-kasus di atas pemasar yang ingin memasarkan green product perlu melihat persepsi dari target pasar. Karena setiap daerah ataupun negara memiliki persepsi yang berbeda-beda terhadap green product. Pemasar perlu mengetahui hal tersebut sebelum melakukan penjualan green product. Hal tersebut bertujuan agar green product tidak dianggap sebelah mata.

Selain itu pemasar perlu memberikan edukasi pentingnya menjaga lingkungan terlebih lagi di daerah yang benar-benar lingkungannya telah rusak. Jika daerah yang lingkungannya baik perlu diberikan edukasi bagaimana mencegah kerusakan lingkungan. Dengan hal tersebut dapat meningkatkan sikap konsumen dan motivasi beli konsumen. Karena dengan adanya edukasi tersebut membuat orang tergerak untuk membeli green product karena mereka merasa berkontribusi untuk menjaga lingkungannya selain alasan kesehatan.

\section{KESIMPULAN DAN SARAN}

Persepsi merupakan apa yang ada di pikiran konsumen. Persepsi konsumen dari berbagai negara kebanyakan memiliki persepsi yang baik. Negara yang memiliki persepsiadalah Nigeria, China, Amerika, India, Hongkong dan Roma untuk orang yang berpendidikan rendah. Hal ini dikarenakan orang mulai peduli dengan lingkungannya dan merasakan manfaat dari produk hijau. Sedangkan negara yang memiliki persepsi rendah adalah Leshoto, New Zealand, Swedia, Korea Selatan dan Roma untuk orang yang berpendidikan tinggi. Hal ini dikarenakan menurut mereka menjaga lingkungan saja sudah cukup dan merek belum merasakan manfaat dari produk hijau. Sedangkan sikap 
merupakan tindakan atau aksi dari konsumen. Orang memiliki sikap dimana mereka mau membeli jika green product tersebut memiliki manfaat yang setimpal dengan harganya. Sedangkan motivasi beli terjadi jika persepsi dan sikap konsumen keduanya positif. Selain didasari persepsi pentingnya menjaga lingkungan dan green product tersebut memiliki nilai yang setimpal maka orang akan termotivasi untuk membeli green product tersebut.

\section{DAFTAR PUSTAKA}

Agustin, Risna , Kumadji, Srikandi , \& Yulianto Edy. 2015. Pengaruh Green Marketing Terhadap Minat Beli Serta Dampaknya Pada Keputusan Pembelian ( Survey Pada Konsumen Non-Member Tupperware di Kota Malang). Jurnal Administrasi Bisnis, Vol. 22, No. 22.

Bathia, Mayank, Jain, Amit. 2013. Green Marketing: A Study of Consumer Perception and Preferences in India. Electronic Green Journal. Vol. 1, No. 36.

Gampu, Anggita, Kawet, Lotje, \& Uhing, Yantje. 2015. Analisis Motivasi, Persepsi, dan Pengetahuan terhadap Keputusan Nasabah Memilih PT. Sulutgo Cabang Utama Manado. Jurnal EMBA, Vol. 3, No. 3.

Gan, Crishopher, Wee, Han, Ozanne, Lucie, Kao, Tzu. 2008. Consumers' Purchasing Behavior Towards Green Products in New Zealand. Innovative Marketing. Vol. 4, Issue 1.

Hawkins, Del I \& David L. Mothersbaugh. 2010. Consumer Behavior Building Marketing Strategy. 11th ed. New York: McGraw-Hill.

Hayu, Rina. 2014. The Influence of Satisfication, Trust and Price of Cunsumer Loyalty of Green Product (Case in Kandang Village Society of Bengkulu City, Wich Have Been Using Energy Saving Lighting Products). Management Insight.Vol. 9, No. 1.

Irandoust, Manuchehr. 2016. Modelling Consumers' Demand for Organic Food Products : Th Swedish Experience. International Journal of Food and Agricultural Economics. Vol. 4, No.3.

Mawey, Hizkia. 2013. Motivasi, Persepsi, dan Sikap Konsumen Pengaruhnya Terhadap Keputusan Pembelian produk PT. Rajawali Nusindo Cabang Manado. Jurnal EMBA, Vol. 1, No.4.

Mini, Vera. 2010. Pengaruh Pengalaman Konsumen Pada Sikap, Persepsi, dan Perilaku yang Ditampakkan Saat Mengalami Ketidakpuasan atau Keluhan: Studi Kasus PDAM di Kota Brebes. Jurnal Ekonomi \& Bisnis. Vol. 4, No. 3.

Nassivera, Federico \&Sillani, Sandro. 2014. Consumer Perception and Motivation Choise of Minimally Processed Vegetables a Case Study in Italy. Biritish Food Journal.

Obayelu, O.A, Adeoti, A.L \& Akinlade, A.A. 2014. Consumers' Willingness to Pay for Labelled and Certified Moringa Products in Ogun State, Nigeria. International.

Saputra, Rico \& Semuel, Hatane. 2013. Analisa Pengaruh Motivasi, Persepsi, Sikap Konsumen, Terhadap Kepuusan Pembelian Mobil Daihatsu Xenia di Sidoarjo. Jurnal Manajemen Permasaran. Vol. 1, no. 1.

Schubert, Fransizka, Kandampully, Jay, Solnet, David, \& Kralj, Anna. 2010. Exploring Consumer Perceptions of Green Restaurants in the US. Totism and Hospitality Research. Vol. 10, No. 4. 
Surya, Aristo \& SetyaningrumAri. 2009. Aplikasi Bauran Pemasaran Serta Hubungannya terhadap Loyalitas Konsumen (Studi Kasus pada Hypermart Cabang Kelapa Gading). Journal of Business Strategy and Execution. Vol. 2, No. 1.

Susilo, Joko. 2012. Pengetahuan Manajemen Tentang Pemahaman Pelanggan dan Pegawai Mengenai Green Product Terhadap Kulaitas Produk yang Dimoderasi oleh Akuntansi Lingkungan dan Kinerja Kualitas. Jurnal Inovasi dan Kewirausahaan. Vol. 1, No. 1.

Tamaka, Irvandy. 2013. Citra Merek, Ekuitas Merek, dan Kualitas Produk Pengaruhnya TerhadapSikap Konsumen Pada Produk Daihatsu di PT. Astra International Daihatsu Manado. Jurnal EMBA, Vol 1, No. 3.

Xie, Biao, Wang, Liyuan, Yang, Hao, Wang, Yanhua, \& Zhang, Mingli. 2014. Consumer Perceptions and Attitude of Organic Food Products in Eastern China.

Yau, Yung. 2012. Eco-labels and Willingness to Pay: a Hong Kong Study. Smart and Sustainable Built Environtment. Vol. 1, No. 3. 